Submission ID: 43790

\title{
Jurassic Sequence Stratigraphy of the Central Caspian Basin
}

\section{I.D. Agapitov* (LUKOIL-Engineering LLC), S.S. Kosova (LUKOIL-Engineering LLC), S.G. Shilkin (LUKOIL-Engineering LLC), A.A. Belova (LUKOIL-Engineering LLC), A.V. Gorban (LUKOIL-Engineering} LLC), I.N. Kerusov (LUKOIL-Engineering LLC)

\section{SUMMARY}

The Middle Caspian offshore is one of a few provinces of Russian shelf with not only explored and proved petroleum resources but also where active production is taking place. Main oil and gas bearing complexes are Jurassic terrigenous-carbonate and Cretaceous terrigenous. Jurassic deposits contain $88 \%$ of petroleum resources within the Sarmat-Kvalyn anticline zone which is a part of Prikum-Central-Caspian system of anticlines and troughs. Current level of exploration gives reasonable level of confidence to identify large and medium structures. New profitable prospects are believed to be found in structural-tectonic and nonanticline traps. Due to good seismic coverage, irregular distribution of drilled wells, long distances between some of zones and lateral changes of thickness and lithology of Jurassic deposits application of sequencestratigraphy analysis is necessary. With application of this method Jurassic deposits were divided into sequences of 2 nd and 3rd order and parasequences for the first time in area of Middle Caspian. Identification of system tracts allowed to describe character of sedimentation in Jurassic basin and to define reservoirs and potential seals and their distribution. 


\section{Сиквенс-стратиграфия юрских отложений акватории Среднего Каспия}

И.Д. Агапитов* (ООО «ЛУКОЙЛ-Инжиниринг»), С.С. Косова (ООО «ЛУКОЙЛИнжиниринг»), С.Г. Шилкин (ООО «ЛУКОЙЛ-Инжиниринг»), А.А. Белова (ООО «ЛУКОЙЛИнжиниринг»), А.В. Горбань (ООО «ЛУКОЙЛ-Инжиниринг»), И.Н. Керусов (ООО «ЛУКОЙЛ-Инжиниринг»)

\section{Введение}

Акватория Среднего Каспия является одной из немногих областей российского шельфа, в пределах которых не только обоснована и доказана продуктивность нефтегазоносных комплексов, но и идут активные работы по разработке уже разведанных месторождений. В тектоническом отношении данный регион относится к эпигерцинской Скифско-Туранской плите. Основными нефтегазоносными комплексами являются юрский и нижнемеловой. К юрским отложениям приурочены около 88 \% всех запасов в пределах Хвалынско-Сарматской приподнятой зоны (залежи месторождений им. Ю.Кувыкина (Сарматское), Хвалынское, 170 км). Части этой зоны, включающей Сарматскую и Южную площади (рис.1), и посвящена данная работа.

Юрский нефтегазоносный комплекс включает два подкомплекса, различающихся литологическими особенностями коллекторов. Нижний (среднеюрский) подкомплекс представлен песчано-алевролитовыми-коллекторами с глинистыми покрышками. Региональной покрышкой служат глинистые известняки и мергели нижней части оксфордского яруса. Продуктивны в среднеюрском подкомплексе отложения ааленского (в Предкавказье), байосского, батского и келловейского ярусов.

Структурный план региона Среднего Каспия изучен достаточно полно для выявления средних и крупных антиклинальных поднятий. В будущем для обеспечения прироста ресурсов УВ потребуется выявление более сложных структурно-тектонических либо неантиклинальных ловушек. С целью оценки возможности формирования подобных объектов в нижнесреднеюрских отложениях был проведён их сиквенс-стратиграфический и палеогеоморфологический анализ.

\section{Методика сиквенс-стратиграфического анализа}

Многие исследователи указывают на необходимость построения надёжной схемы стратификации юрского разреза для Среднего Каспия. Традиционная стратиграфия очень слабо расчленяет нижнесреднеюрские отложения. В основном, кроме кровли и подошвы выделяется еще одна граница - поверхность нерасчлененных бат-байосских отложений. Данная ситуация обусловлена как низкой разбуренностью в регионе этой части разреза, так и значительной латеральной изменчивостью литологии осадочных комплексов.

Наряду с хорошей сейсмической изученностью территории отмечается неравномерное распределение по площади пробуренных скважин, часто разделенных большими расстояниями (до $\mathrm{n} * 10 \kappa м)$. Корреляция в межскважинном пространстве осложняется значительной литофациальной изменчивостью юрских отложений, что определяет необходимость выполнения сиквенс-стратиграфического анализа, включающего сейсмические, стратиграфические и седиментологические исследования [Van Wagoner et al., 1990]. Выделение сиквенсов по данным ГИС и материалам сейсморазведки, прослеживание их по площади, привлечение дополненных литолого-фациальных, палеонтологических скважинных данных, позволяют создать детальную корреляционную схему, определить последовательную смену латеральной изменчивости фаций и представить достоверную модель развития осадочного бассейна или его частей с высокой прогнозной способностью. Также важную роль для прогноза коллекторов играет палеогеоморфологический анализ изучаемых сиквенсов, 


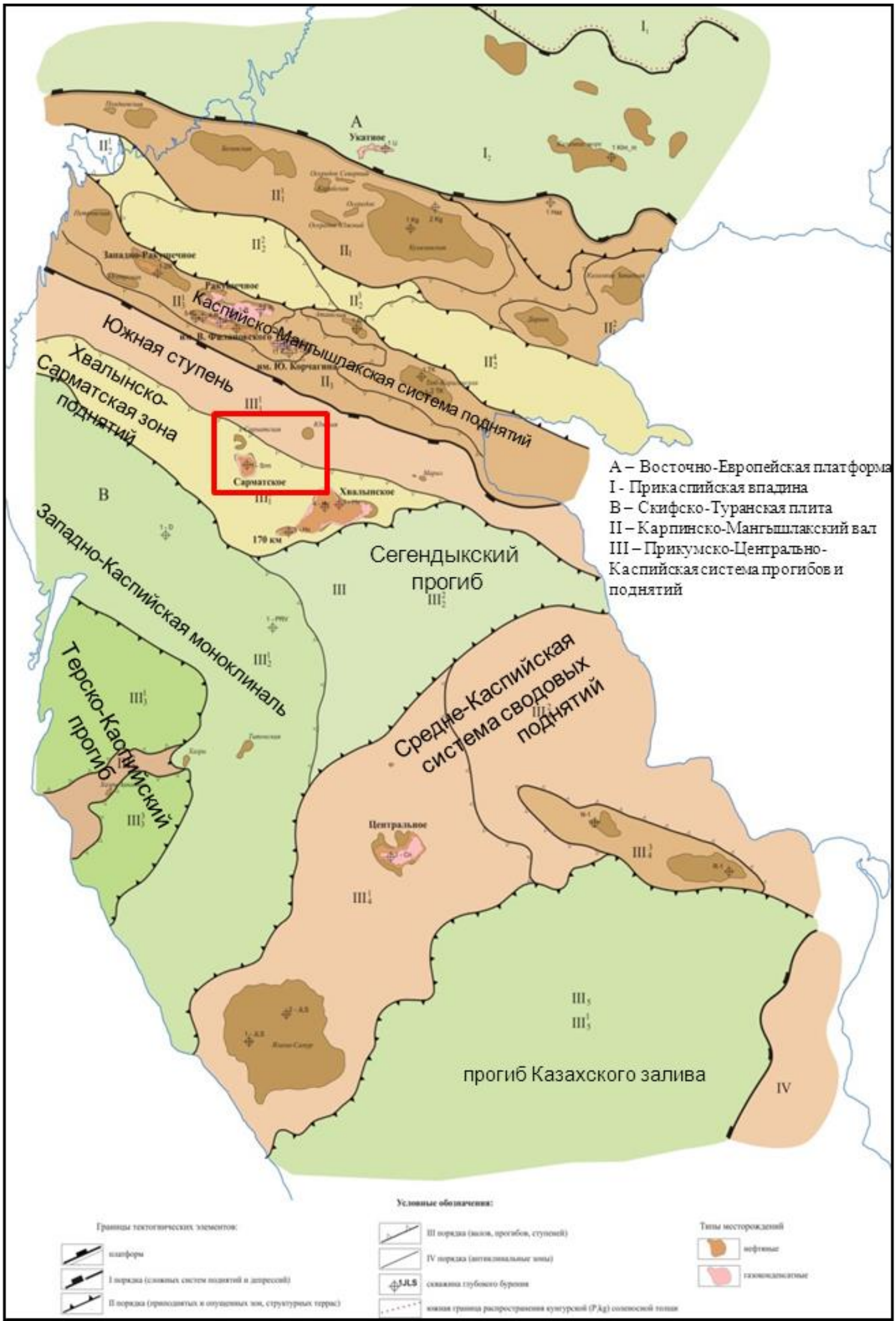

Рисунок 1 Схема тектонического районирования юрско-миоченового комплекса отложений акватории Северного и Среднего Каспия [Медведев и др., 2008] с указанием положения района исследований 
позволяющий корректно интерпретировать результаты динамического анализа.

\section{Результаты}

В ходе многолетних исследований, проводимых сотрудниками ООО «ЛУКОЙЛ-Инжиниринг» и СК «Петроальянс», в разрезе Среднего Каспия был выделен один сиквенс первого порядка Мезо-Кайнозойский, охватывающий период от среднего триаса по современное время продолжительностью около 225 млн. лет. В её составе выделяется семь сиквенсов второго порядка длительностью от 19 до 46,5 млн. лет (раннесреднеюрский, позднеюрский, раннемеловой, позднемеловой, палеоцен-эоценовый, олигоцен-миоценовый и плиоценчетвертичный).

На протяжении юрского периода отмечается тренд повышения глобального уровня моря. Иными словами, юрские отложения формировались в трансгрессивный период развития МезоКайнозойской сиквенса 1-го порядка. Наиболее полно данные отложения представлены на юге в скважинах Хвалынской и Центральной площадей. В кровле и подошве рассматриваемый комплекс ограничивается поверхностями несогласий - предъюрским (SB JT) и предмеловым (SB J3). Внутрикомплексное предпозднеюрское несогласие (SB J2) разделяет юрский комплекс на два сиквенса 2-го порядка: раннесреднеюрский и позднеюрский. В целом нижнесреднеюрские отложения формировались в условиях трансгресии моря от Центрального поднятия к Ракушечно-Широтному валу [Керусов и др., 2015]. Отложения среднего отдела юры разделены на 11 сиквенсов 3-го порядка (J2s1-J2s11) в районе Центральной площади, которая в юрское время располагалась в пониженной части бассейна седиментации. В составе нижнесреднеюрского сиквенса 2-го порядка среднеюрские отложения соответствуют тракту высокого стояния моря (HST).

В районе Сарматских структур и Ракушечно-Широтной зоны раннеюрские отложения предположительно не накапливались, трансгрессия дошла до этих регионов лишь в начале среднеюрского времени. Только в самой раннем сиквенсе J2s1 «холмистый» тип сейсмической записи позволяет наметить на временных разрезах латерально ограниченные седиментационные тела - предположительно конуса выноса, продвигавшиеся в сторону депоцентра бассейна по мере отступления уровня моря. Сиквенсы J2s2 и J2s3, предположительно отвечающие ааленским и раннебайосским отложениям, в пределах Сарматской и Южной площадей выклиниваются на поверхность ОГ ЈT, что может послужить возможной зоной формирования неантиклинальных ловушек.

Анализ нефтегазоносности всех среднеюрских сиквенсов позволил установить, что интересными с позиции поиска залежей УВ в Хвалынско-Сарматской зоне являются сиквенсы $\mathrm{J} 2 \mathrm{~s} 9$ и J2s10, соответствующие батским и келловейским отложениям. Из них промышленные залежи УВ выделяются в сиквенсе J2s10.

В бат-келловейское время изучаемый район располагался в области перехода от Ракушечной системы мелководных палеоотмелей, служившей источником сноса осадочного материала, к равнинам палеошельфа. Детальный палеогеоморфологический анализ на основе $3 Д$ сейсмических данных в пределах Сарматской и Южной площадей продемонстрировал существование в данное время Сарматского и Южного палеоподнятий, равнин палеошельфа и, предположительно, погруженных областей шельфа (рис.2). Все выделенные элементы палеорельефа естественным образом контролировали направления транспортировки осадочного материала, его дифференциацию и места накопления. Основные направления перемещения терригенного материала в бат-келловейское время показаны на рисунке 2.

\section{Выводы}

Выполненный сиквенс-стратиграфический анализ среднеюрского комплекса позволил установить, что наиболее перспективными отложениями для формирования объектов 


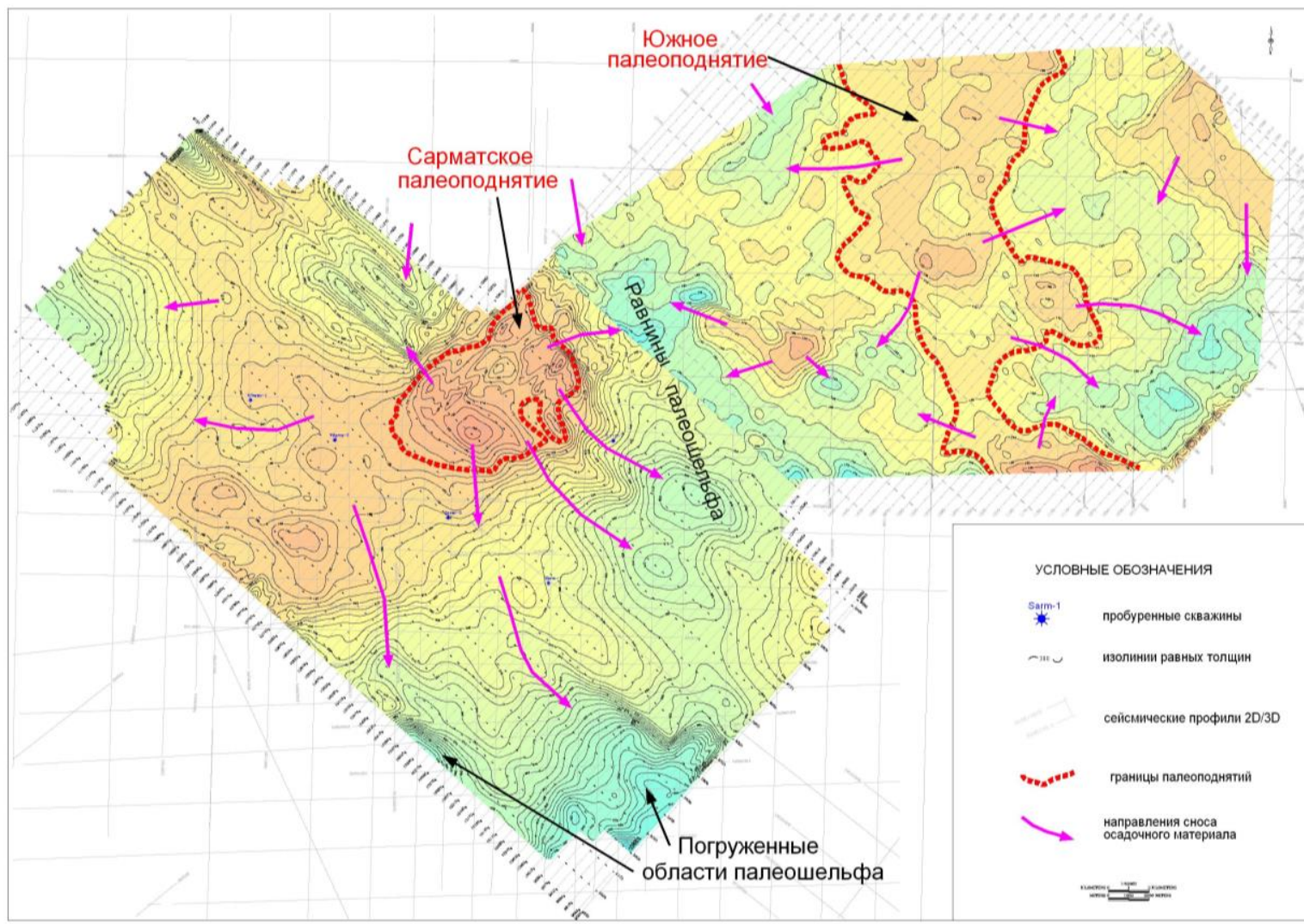

Рисунок 2 Палеогеоморфологическая схема бат-келловейских отложений (сиквенсы J2s9J2s11) для Сарматской и Южной площадей на основе карт толщин. Коричневыми тонами показаны относительно приподнятые области, голубыми - относительно погруженные

структурно-литологического генезиса в Хвалынско-Сарматской зоне и прилегающих территорий являются келловейские сиквенсы, завершающие тракты высокого стояния раннесреднеюрского сиквенса 2-го порядка. Вторым уровнем формирования структурнолитологических ловушек являются базальные отложения комплекса, выклинивающиеся вверх по восстанию на север, и перекрытые преимущественно глинистыми отложениями трансгрессивных системных трактов. Наиболее обоснованно объекты подобного генезиса выделяются по данным ЗД сейсморазведки.

\section{Библиография}

Керусов, И.Н., Косова, С.С., Шилкин, С.Г., Горбань, А.В. и Белова, А.А. [2015] Секвенсная стратиграфия юрско-нижнемеловых отложений Ракушечно-Широтной структурной зоны. Принципы и методы изучения нефтегазовых месторождений: Сб.статей Филиала ООО «ЛУКОЙЛ-Инжиниринг» «ВолгограНИПИморнефть» в г.Волгограде. Волгоград, вып. 73.

Медведев, П.В., Попович, С. В. и Куклинский, А.Я. [2008] Тектоническое строение и некоторые вопросы нефтегазогеологического районирования платформенного чехла акватории Северного и Среднего Каспия (в пределах Скифско-Туранской платформы). Bonpocbl геологии и перспективы нефтегазоносности Нижнего Повольья и Каспийского моря: Сб. науч. тр. ООО «ЛУКОЙЛ-ВолгограНИПИморнефть». Волгоград, вып. 67.

Van Wagoner, J.C., Mitchum, R.M., Campion, K.M. and Rahmanian, V.D. [1990] Siliciclastic Sequence Stratigraphy in Well Logs, Cores and Outcrops. AAPG Methods in Exploration Series, №7. 


\section{EAGE}

\section{Bibliography}

Kerusov, I.N., Kosova, S.S., Shilkin, S.G., Gorban, A.V. and Belova, A.A. [2015] Sekvensnaya stratigrafiya yursko-nizhnemelovyh otlozhenij Rakushechno-Shirotnoj strukturnoj zony. Principy $i$ metody izucheniya neftegazovyh mestorozhdenij: Sb.statej Filiala OOO «LUKOJL-Inzhiniring» «VolgograNIPImorneft'»v g.Volgograde. Volgograd, vyp. 73.

Medvedev, P.V., Popovich, S. V. and Kuklinskij, A.Ya. [2008] Tektonicheskoe stroenie i nekotorye voprosy neftegazogeologicheskogo rajonirovaniya platformennogo chekhla akvatorii Severnogo i Srednego Kaspiya (v predelah Skifsko-Turanskoj platformy). Voprosy geologii i perspektivy neftegazonosnosti Nizhnego Povolzh'ya i Kaspijskogo morya: Sb. nauch. tr. OOO «LUKOJLVolgograNIPImorneft'». Volgograd, vyp. 67.

Van Wagoner, J.C., Mitchum, R.M., Campion, K.M. and Rahmanian, V.D. [1990] Siliciclastic Sequence Stratigraphy in Well Logs, Cores and Outcrops. AAPG Methods in Exploration Series, №7. 